\title{
Examining Banks Profitability and Banks Efficiency of Islamic Commercial Banks in Indonesia
}

\author{
Drs. Chandra Setiawan and Onie Insany Kodratillah
}

\begin{abstract}
This research investigates: first, the Return on Assets (ROA) determinants of Islamic commercial banks in Indonesia period of 2012Q1 - 2016Q2 using panel least square by adopting Fixed Effect Method (FEM); second, measuring the technical efficiency level using Data Envelopment Analysis (DEA) approach; third, the relationship between technical efficiency and Return on Assets (ROA) using simple regression. This research uses time series and quarterly published report data from Central Bank (Bank Indonesia). The results as follows: Size (log total assets), Operational Efficiency Ratio (OER), Net Profit Margin ratio (NPM), Financing to Deposit Ratio (FDR), and $B I$ rate have partially and simultaneously significant effect toward Return on Assets (ROA). The average technical efficiency of Islamic commercial banks is 0.919 or $91.9 \%$. This finding indicates that Bank Negara Indonesia Syariah (BNIS) in the research period as the most technical efficiency. It shows that in overall Islamic commercial banks is still inefficient in managing their performance. The finding reveals there is no significant relationship between Technical Efficiency and Return on Asset.
\end{abstract}

Keyword: Islamic Commercial Banks, Profitability, Data Envelopment Analysis, Technical Efficiency.

\section{Introduction}

Indonesia is the country with the largest Muslim population, and the first Islamic cooperative were established in 1990, followed by rural banks in 1991, and the first Islamic commercial banks in 1992 (Seibel, 2008; Abdu \& Omar, 2012). In 1998, Central bank officially introduce, as part of a new banking act, to the awareness of dual banking systems, conventional and Islamic, or based on syariah (Seibel, 2008).

According to Bank of International Settlement (2008), the root of this crisis refers to the extravagant lending by conventional banks. While, the effect to Islamic commercial banks was minor in financial crisis comparing conventional banks (Chapra, 2008). It is happened because of Islamic commercial banks do not dealing with debt trading and speculative transaction. The operations of Islamic financial institutions are based on a profit and loss sharing and Islamic law. Islamic commercial banks do not charge interest for the financing activity. Islamic banking was distinguished by the fact that buying debts are prohibited in Islamic law. Therefore, Islamic commercial banks are safer compared to conventional banks from the effects of the global financial crisis.

Dr. Drs. Chandra Setiawan, M.M., Ph.D, Management Study Program, Faculty of Business, President University, Indonesia, E-mail: chandra@president.ac.id

Onie Insany Kodratillah, Management Study Program, Faculty of Business, President University, Indonesia, E-mail: onieinsany@gmail.com 
In this research, the performance of banks is evaluated by the financial performance. Theoretically, there are some indicators to measure the bank's profitability, such as Return on Assets (ROA), Return on Equity (ROE), and Net Profit Margin (NPM). Meanwhile, this research will focus on Return on Assets (ROA) since, in addition Indonesia central bank prioritize ROA than ROE to measure the performance of the banks, because the priority value of a bank's profitability measured by assets which funds sources most come from public deposits (Dendawijaya, 2005). Return on Assets (ROA) is a major indicator of profitability banks (Siraj and Pillai, 2012. According Samad and Hassan, 2010 the higher ratio of ROA will indicates the higher ability and therefore it is an indicator of the better performance. Higher ROA means that the profit is better and it is good regarding utilizing the assets and it's shown how well bank can convert asset into net earnings.

Therefore, to compete in this industry, Islamic banks should have good performance and operate in efficient way. The Islamic banks can achieve maximum profit and productivity also be able to maintain the financial health. Since act number 21 of 2008 concerning about Islamic banking issued, the existence of Islamic banks keeps in increasing. Moreover, until June 2016 the total number of Islamic commercial banks is 12 , the total number of Islamic business unit is 22 , and the total number of Islamic rural banks is 165 . Also, the number of total assets are kept increase since the last decade, in June 2016 the total assets is IDR 306,225 billion.

However, the increasing number banks and assets it does not followed by the stability improvement of the profitability that reflected by Return on Assets (ROA) ratio. Based on Islamic Banking Statistics published by Indonesia central bank (Bank Indonesia) over 6 years, averagely the ROA trends of Islamic commercial banks are fluctuated. Moreover, starting from 2013 the trend of ROA is decreasing and about to keep away from the Indonesia central bank standard which $1.5 \%$. The highest level was in January 2013 which is $2.52 \%$ and for the lowest level was in February 2014 which is $0.13 \%$. Therefore, profitability of Islamic commercial banks in Indonesia still need to pay attention and to be concerned, due the poor performance that can be explored in Table 1.

This research intends to measure technical efficiency of Islamic commercial banks in Indonesia through Data Envelopment Analysis (DEA) approach to find whether Islamic commercial banks in Indonesia already technically efficient or not. The research question here is how ROA affects the banks efficiency. Wahab (2015) found that ROA positive and insignificant to technical efficiency. The increase of ROA does not affect the technical efficiency. 
Table 1: ROA Ratio of Islamic Commercial Banks and Islamic Business Unit in Indonesia (January 2010 - June 2016)

\begin{tabular}{|l|l|l|l|l|l|l|l|}
\hline \multirow{2}{*}{ Month } & \multicolumn{7}{|c|}{ ROA Ratio } \\
\cline { 2 - 8 } & $\mathbf{2 0 1 0}$ & $\mathbf{2 0 1 1}$ & $\mathbf{2 0 1 2}$ & $\mathbf{2 0 1 3}$ & $\mathbf{2 0 1 4}$ & $\mathbf{2 0 1 5}$ & $\mathbf{2 0 1 6}$ \\
\hline January & $1.65 \%$ & $2.26 \%$ & $1.36 \%$ & $2.52 \%$ & $0.08 \%$ & $0.88 \%$ & $1.01 \%$ \\
\hline February & $1.76 \%$ & $1.81 \%$ & $1.79 \%$ & $2.29 \%$ & $0.13 \%$ & $0.78 \%$ & $0.81 \%$ \\
\hline March & $2.13 \%$ & $1.97 \%$ & $1.83 \%$ & $2.39 \%$ & $1.16 \%$ & $0.69 \%$ & $0.88 \%$ \\
\hline April & $2.06 \%$ & $1.90 \%$ & $1.79 \%$ & $2.29 \%$ & $1.09 \%$ & $0.62 \%$ & $0.80 \%$ \\
\hline May & $1.25 \%$ & $1.84 \%$ & $1.99 \%$ & $2.07 \%$ & $1.13 \%$ & $0.63 \%$ & $0.16 \%$ \\
\hline June & $1.66 \%$ & $1.84 \%$ & $2.05 \%$ & $2.10 \%$ & $1.12 \%$ & $0.50 \%$ & $0.73 \%$ \\
\hline July & $1.67 \%$ & $1.86 \%$ & $2.05 \%$ & $2.02 \%$ & $1.05 \%$ & $0.50 \%$ & \\
\hline Augustus & $1.63 \%$ & $1.81 \%$ & $2.04 \%$ & $2.01 \%$ & $0.93 \%$ & $0.46 \%$ & \\
\hline September & $1.77 \%$ & $1.80 \%$ & $2.07 \%$ & $2.04 \%$ & $0.97 \%$ & $0.49 \%$ & \\
\hline October & $1.79 \%$ & $1.75 \%$ & $2.11 \%$ & $1.94 \%$ & $0.56 \%$ & $0.51 \%$ & \\
\hline November & $1.83 \%$ & $1.78 \%$ & $2.09 \%$ & $1.96 \%$ & $0.49 \%$ & $0.52 \%$ & \\
\hline December & $1.67 \%$ & $1.79 \%$ & $2.14 \%$ & $2.00 \%$ & $0.41 \%$ & $0.49 \%$ & \\
\hline
\end{tabular}

\section{Adjusted by Author, data based on Islamic Banking Statistics Published by OJK}

This research is focusing on Islamic commercial banks in Indonesia. By determine the significant variables that affect the ROA of Islamic commercial banks in Indonesia and to examine the technical efficiency of Islamic commercial banks in Indonesia by using Islamic commercial banks inputs-outputs; also founded the relationship between ROA and technical efficiency of Islamic commercial banks in Indonesia.

The organization of this research as follows. Section 2 literature reviews. Section 3 describe the data, sources, and methodology, which is employed in this research. The empirical results are provided in section 4 . Section 5 is the conclusion.

\section{Literature Review}

The previous research about Return on Asset (ROA) in Islamic banks and bank efficiency of the Islamic banking system has been found in several banking and finance research. Determinants of Return on Asset (ROA) and bank efficiency have been selected for the arisen theoretical and empirical investigations in this research.

\subsection{Return on Asset Determinants}

Factors that impact ROA can be caused by internal and external factors according to (Syafri, 2012, p.237). In order to find the problems, variable of internal factors which will be used in this research are: Size ratio, Operational Expenses Ratio (OER), Net Profit Margin (NPM), and Financing to Deposit Ratio (FDR). Short (1979), Smirlock (1985), and Akhavein (1985) found that Size has a positive and significant impact toward ROA. Size is the measurement form that can be measured by natural logarithm from the total assets (Amaeur, I and Mhiri,s, 2013). Size is a tool to measure the size or standard assets of its company. Hence, the value of Size increase the value of ROA also increase and vice versa. Muh Sabir, Muhammad Ali, and Abd Hamid Habbe 
(2012) found that OER has a negative and significant impact toward ROA. When the value of OER is decrease the value of ROA will increase and vice versa. OER shows the operational activities within the banks, the higher OER means that the value of ROA become small. It happened because banks cannot press the operational expenses, therefore its effect return of profit. Maria Regina Rosaria Sianturi (2012) and Marnov PP Nainggolan (2009) found that NPM has a positive and significant impact toward ROA. This ratio shows the capability of company to generate the net profit. When the value of NPM is increase then the value of ROA will increase also and vice versa. Nugroho (2011) and Fadjar (2013) found that FDR has a positive and significant impact toward ROA. FDR is how far the banks' ability to repay the withdrawal of funds by depositors by controlling the financing as a source of liquidity. According to Muhammad, 2005 FDR is how much third party funds be released for financing Islamic banks. Variable of external factor which will be used in this research is $\mathrm{BI}$ rate. Neni Supriyanti (2009) found that BI rate has a negative and significant impact toward ROA. Interest rate is one of the monetary indicator that has effect in several of economic activities, Herman Darmawi (2006:188). When the value of $\mathrm{BI}$ rate is decrease then the value of ROA will increase and vice versa. $\mathrm{BI}$ rate will affect the profitability of the banks. When $\mathrm{BI}$ rate increase, it will be followed by the increasing of deposit rate that directly affect toward the decreasing of the third parties resources fund of Islamic banks. Karim (2009) found that when the third parties fund is decrease, the profitability of Islamic banks will experience decrease.

\subsection{Bank Efficiency}

Supriyono (2007) point out that efficiency is if unit can work in the good way, so that can reach the target or the goal that being expected. Research about efficiency, especially with frontier approach toward banking was begun by Sherman and Gold (1985). Ascarya and Yumanita (2005) found that there are two kind of efficiency, which are technical efficiency and economic efficiency. Measurement by using technical efficiency are by the relations of technical and operations of inputs and outputs conversion. This research uses nonparametric technique which uses linear programming method through Data Envelopment Analysis (DEA). According Sherman and Zhu, 2006 and cited by Zhu, 2009 DEA is an excellent tool for improving the productivity of business service. DEA has some advantages; DEA more flexible in terms of its ability to take into accounts for multiple outputs and inputs in estimating the efficiency (Suzuki and Sastrosuwito, 2011). In addition, DEA works relatively well with small sample. Andries (2013), and Fathony (2015) found that there is no relationship between technical efficiency and ROA. Wahab (2015) found that ROA has no a significant impact to technical efficiency. The positive value of profitability does not mean always support that the value of bank efficiency is better or even bad and vice versa.

\section{Methodology}

\subsection{Research Questions}

1. What factors that give significant effect and how those factors affect on Return on Assets (ROA) of Islamic commercial banks during period 2012Q1 -2016 Q2? 
2. How does the efficiency level of Islamic commercial banks in Indonesia during period 2012Q1 - 2016Q2?

3. How does the relations between technical efficiency and profitability of Islamic commercial banks in Indonesia during period 2012Q1 - 2016Q2?

\subsection{Modeling Return on Asset Determinants and Technical Efficiency}

\subsubsection{Estimation of Determinants of Return on Asset}

The application software that used in analyzing the determinant factors of ROA is eviews version 8. According to Schwert, 2010 Eviews has an advantage in the visual features of modern Windows software. Panel data also known as cross-section time series data it is a set of data in which behavior of entities is observed across time (Torres, O. \& Reyna, 2007). Panel regression model has three alternative model for the estimation results. There are (1) Common Effect Model (The Pooled OLS Method), (2) Fixed Effect Model (FEM), and (3) Random Effect Model (REM). In order to find the right model, the Chow test and Hausman test is conducted. Because of the crosssection data $(\mathrm{N})$ in this research is lower than the number of independent variable therefore Hausman test cannot be used, meanwhile, this research was used fix effect model. According to Gujarati (2005), as cited by Setiawati \& Setiawan (2013), fixed effect model assumes the slope of each variables is constant, but the intercept is different for each cross- section unit and constant for every time series unit. In order to check the chow test is conducted.

In this research, internal and external factors are used to find the significant variables that affect on ROA of Islamic banks. The internal factors are represented by Size, OER, NPM, and FDR. Whereas BI rate is represented of external factor. Panel regression of the determinants of Return on Assets (ROA), as follows:

$$
\begin{aligned}
& Y_{i t}=\alpha_{i}+\beta 1 X_{i t, 1}+\beta 2 X_{i t,}+\beta 3 X_{i t,} 3+\beta 4 X_{i t,} 4+\beta 4 X_{i t,} 5+\varepsilon i t \\
& W h e r e: \\
& Y=\text { Return on Assets } \\
& \alpha=\text { constant } \\
& X 1=\text { Size (log total assets) } \\
& X 2=\text { Operational Efficiency Ratio (OER) } \\
& X 3=\text { Net Profit Margin Ratio (NPM) } \\
& X 4=\text { Financing to Deposit Ratio (FDR) } \\
& X 5=\text { BI Rate } \\
& \beta 1=\text { Determine the contribution of Size (Coefficient regression of Size) } \\
& \beta 2=\text { Determine the contribution of OER (Coefficient regression of OER) } \\
& \beta 3=\text { Determine the contribution of NPM (Coefficient regression of NPM) } \\
& \beta 4=\text { Determine the contribution of FDR (Coefficient regression of FDR) } \\
& \beta 5=\text { Determine the contribution of BI rate (Coefficient regression of BI } \\
& \quad \text { rate) } \\
& i \quad=\text { Total number of banks } \\
& t \quad=\text { Total number observations for each bank } \\
& \varepsilon \quad=\text { Composite error term }
\end{aligned}
$$


This research applied t-test to see the effect of partially or each independent variables to the dependent variable by comparing value of significant $t$ with significant standard $\alpha=0.05$.

The hypotheses of this research are as follows:
$\mathrm{Ho}_{1}$ : There is no significant effect of Size toward ROA.
$\mathrm{Ha}_{1}$ : There is a significant effect of Size toward ROA.
$\mathrm{Ho}_{2}$ : There is no significant effect of OER toward ROA.
$\mathrm{Ha}_{2}$ : There is a significant effect of OER toward ROA.
$\mathrm{H}_{3}$ : There is no significant effect of NPM toward ROA.
$\mathrm{Ha}_{3}$ : There is a significant effect of NPM toward ROA.
$\mathrm{Ho}_{4}$ : There is no significant effect of FDR toward ROA.
$\mathrm{Ha}_{4}$ : There is a significant effect of FDR toward ROA.
$\mathrm{Ho5}_{5}$ : There is no significant effect of $\mathrm{BI}$ rate toward ROA.
$\mathrm{Ha}_{5}$ : There is a significant effect of $\mathrm{BI}$ rate toward ROA.

Besides t-test, F-test is performed to test the simultaneous effect of independent variables to dependent variable. Before the hypothesis test, classical assumption test is conducted through normality test, heteroscedasticity test, autocorrelation test, and multicollinearity test.

\subsubsection{Estimation of Technical Efficiency}

To measure the technical efficiency of Islamic banks, this research uses the software of MaxDea version 6.13 to run DEA-VRS (Data Envelopment Analysis - Variable Return to Scale). DEA was developed by Banker, Charnes, and Cooper in 1984 known as BCC model it is assume the ratio between inputs and outputs are different (variable return to scale).

Table 2: Envelopment Models

\begin{tabular}{l|l}
\hline Frontier Type & Input-Oriented \\
\hline CRS & $\min \theta-\varepsilon\left(\sum_{i=1}^{m} s_{i}^{-}+\sum_{r=1}^{s} s_{r}^{+}\right)$ \\
& subject to \\
& $\sum_{j=1}^{n} \lambda_{j} x_{i j}+s_{i}^{-}=\theta x_{i o} i=1,2, \ldots, \mathrm{m} ;$ \\
& $\sum_{i=1}^{n} \lambda_{j} y_{r j}-s_{r}^{+}=y_{r o} r=1,2, \ldots \mathrm{s} ;$ \\
& $\lambda_{j} \geq 0 j=1,2, \ldots, n$. \\
\hline VRS & $\operatorname{Add~} \sum_{j=1}^{n} \lambda_{j}=1$ \\
\hline
\end{tabular}

Source: Zhu (2009)

The value of technical efficiency ranges zero to one, where a value of one indicates full efficiency. According to Amirillah (2010), Islamic banks are efficient if the efficiency score is equal to one. In this research, the inputs-outputs variables to calculate technical efficiency are adapted from Hoque \& Rayhan (2012). The variables consist of inputs and outputs: 
Proceedings of 12th Asia-Pacific Business Research Conference 27 - 28 February, 2017, Concorde Hotel, Kuala Lumpur, Malaysia ISBN: 978-1-925488-29-6

Table 3: Variables and Operational Definition of Bank Technical Efficiency

\begin{tabular}{|c|c|c|}
\hline Variable & Variable Names & Operational Definition \\
\hline \multicolumn{3}{|l|}{ Inputs } \\
\hline $\mathrm{X} 1$ & Total Funds & $\begin{array}{l}\text { Total funds that consist of giro wadhi'ah, } \\
\text { mudharabah saving, and mudharabah } \\
\text { deposit }\end{array}$ \\
\hline $\mathrm{X} 2$ & $\begin{array}{l}\text { Operational } \\
\text { Employees }\end{array}$ & Personal Expenses \\
\hline $\mathrm{X} 3$ & Total Assets & Fix Assets + Inventories \\
\hline \multicolumn{3}{|l|}{ Outputs } \\
\hline Y1 & Total Financing & $\begin{array}{l}\text { Total Financing consist of murabahah, } \\
\text { mudharabah, musyarakah, istishna, qard, } \\
\text { and ijarah }\end{array}$ \\
\hline Y2 & $\begin{array}{l}\text { Total Operating } \\
\text { Income }\end{array}$ & Only total operating income \\
\hline
\end{tabular}

\subsubsection{Relationships between technical efficiency and ROA}

Simple regression model is used to determining the relationships between technical efficiency and ROA. Simple regression was popular by the book of Snedecor and Cochrn (1980) develop results using simple algebra and summation notation. The model for the simple regression is:

$$
\begin{aligned}
& Y=a+b X \\
& \text { Where: } \\
& Y \quad=\text { Dependent Variable } \\
& X \quad \text { Independent Variable } \\
& \mathrm{a} \quad \text { = Constant } \\
& \mathrm{b}=\text { Regression coefficient (slope) } \\
& \text { Equation as follow: }
\end{aligned}
$$

Ho1 : The sum of technical efficiency estimated of Islamic commercial banks is associated insignificant with Return on Assets.

$\mathrm{Ha}_{1}$ : The sum of technical efficiency estimated of Islamic commercial banks is associated significant with Return on Assets.

\subsection{Data}

This research used secondary data that consist of quarterly financial ratios of Islamic commercial banks and macroeconomic indicator. Those data are gathered from the official websites of Indonesia Bank, the official banks website and Central Agency of Statistics (BPS) that published by Financial Services Authority (OJK). Data are collected from sources that already exist and can be gathered from related books, journals, previous research, and related websites (Sekaran \& Bougie, 2011).

The population of this research is all Islamic commercial banks that operate during 2012Q1 - 2016Q2 which is 12 banks. For the sample size, this research applied nonprobability sampling with focus on purposive sampling due to the certain purpose that want to be achieved in this research. Purposive sampling is a technique to take the sampling with the certain purpose, to determining the sample of the research (Sekaran \& Bougie, 2011), with the criteria are Islamic banks which do not have out layered data 
during period 2012Q1-2016Q2. Another criteria is the Islamic commercial banks which having the decreasing of the Return on Assets (ROA) based on circular letter of Indonesia central bank to all commercial banks based on syaria principles in Indonesia No. 9/24/DPbs, Jakarta, October 30, 2007, is below 1.5\%, during period 2012Q12016Q2. There are 4 out of 12 Islamic commercial banks that to be used, these banks are banks that have below of ROA standard which are; Bank Mandiri Syariah (BSM), BNI Syariah (BNIS), BRI Syariah (BRIS), and BCA Syariah (BCAS).

To determine the factors that affect on ROA of Islamic commercial banks in Indonesia, panel data regression method is applied. Technical efficiency is measured by calculating inputs-outputs through an envelopment model function. The relationships between technical efficiency and ROA through simple regression model.

\section{Result and Discussion}

To find the factors of ROA determinants, Fixed Effect Model is applied as the estimation model due to the result of the Chow test. The table 4 shows the result of panel regression result with FEM.

\begin{tabular}{|c|c|c|c|c|}
\hline $\begin{array}{l}\text { Dependent Variable: } \\
\text { Method: Panel Least } \\
\text { Date: } 11 / 30 / 16 \text { Time } \\
\text { Sample (adjusted): } 3 \\
\text { Periods included: } 18 \\
\text { Cross-sections inclu } \\
\text { Total panel (balance } \\
\text { White cross-section }\end{array}$ & $\begin{array}{l}\text { ares } \\
40 \\
20126 / 01 / 20 \\
4 \\
\text { servations: } \\
\text { dard errors \& }\end{array}$ & $\begin{array}{l}16 \\
2 \\
\text { covariance (c }\end{array}$ & corrected) & \\
\hline Variable & Coefficient & Std. Error & t-Statistic & Prob. \\
\hline SIZE & 1.340638 & 0.373159 & 3.592669 & 0.0006 \\
\hline OER & -12.30863 & 0.725565 & -16.96419 & 0.0000 \\
\hline FDR & 1.839887 & 0.575341 & 3.197907 & 0.0022 \\
\hline NPM & 0.069143 & 0.018804 & 3.676959 & 0.0005 \\
\hline BI_RATE & -0.136148 & 0.061126 & -2.227349 & 0.0295 \\
\hline $\mathrm{C}$ & 12.26205 & 3.395406 & 3.611365 & 0.0006 \\
\hline \multicolumn{5}{|c|}{ Effects Specification } \\
\hline \multicolumn{5}{|c|}{ Cross-section fixed (dummy variables) } \\
\hline R-squared & 0.889429 & \multirow{7}{*}{\multicolumn{2}{|c|}{$\begin{array}{l}\text { Mean dependent var } \\
\text { S.D. dependent var } \\
\text { Akaike info criterion } \\
\text { Schwarz criterion } \\
\text { Hannan-Quinn criter. } \\
\text { Durbin-Watson stat }\end{array}$}} & 1.045833 \\
\hline Adjusted R-squared & 0.875388 & & & 0.534915 \\
\hline S.E. of regression & 0.188827 & & & -0.379498 \\
\hline Sum squared resid & 2.246315 & & & -0.094915 \\
\hline Log likelihood & 22.66193 & & & -0.266205 \\
\hline F-statistic & 63.34608 & & & 1.702036 \\
\hline Prob(F-statistic) & 0.000000 & & & \\
\hline
\end{tabular}

Table 4: Regression Model Result

Source: Data processed with Eviews version 8

The result shows the t-statistic of SIZE is 3.593 with a significant level of 0.000 . It indicates that SIZE has a positive and significant effect on ROA. This result was supported by Short (1979), Smirlock (1985), and Akhavein (1985). Size is one of aspects to measure the banks. Through the proxy from the total assets, the investor could assume which level its bank is. The more total assets that possessed by the banks, the more profit will be earned by the banks. The t-statistic of OER is -16.964 with a significant level of 0.000 . It indicates that OER has a negative and significant 
effect on ROA. Operating Efficiency Ratio (OER) measures the operational risk of Islamic banks through the comparison between operational expenses to operational incomes. Banking industry should have trust for the operational activities that generate higher operational income from its operational expense (Rivai et al., 2007). The higher number will reduce the profitability therefore, Islamic commercial banks should pay attention regarding maintaining OER. This result was supported by Muh Sabir, Muhammad Ali, and Abd Hamid Habbe (2012). The t-statistics of FDR is 3.198 with a significant level of 0.002 . It indicates that FDR has a positive and significant effect on ROA. Financing to Deposit Ratio (FDR) measures the liquidity of Islamic commercial banks which indicate the higher ratio. It shows that the banks are not liquid effect the decreasing of the profitability. When the banks are not liquid, the banks would face high liquidation risk which liquid asset is not available to fulfill the obligations of the customers. This caused will affect the trust of the customers in banking industry. The decreasing of the trust will impact to drawing the fund that effected to the lower liquidation. Hence, according to Werdaningtyas, 2002; cited in Sartika, 2012 stated that it causes the decreasing of the liquidation. This result was supported by Muh Sabir, Muhammad Ali, and Abd Hamid Habbe (2012), and Fadjar (2013). The t-statistic of NPM is 3.677 with the significant level of 0.000 . It indicates that NPM has a positive and significant effect on ROA. Net Profit Margin shows the capability of company to generate the net profit. Based on Weston and Copeland (1998), the higher of NPM will reflect the efficiency level of the company regarding to generate the expense through operational activities. This result was supported by Maria Regina Rosaria Sianturi (2012) and Marnov PP Nainggolan (2009). The t-statistic of BI rate is -2.227 with the significant level of 0.030 . It indicates that $\mathrm{BI}$ rate has a negative and significant effect on ROA. According to Herman Darmawi (2006: 188) interest rate is one of the monetary indicator that has effect in several of economic activities. BI rate will influence the bank's profitability. When BI rate increase, it will be followed by the increasing of deposits rate that directly affect toward the decreased of third parties' resources fund of Islamic banks. The decreased of third parties fund will impact the community fund because they tend to have the transaction toward conventional bank for gaining the higher return of interest. Meanwhile, the third parties fund decreased, so the profitability of Islamic banks will experience decreased (Karim, 2006). This result was supported by A.A Putri Suardani (2009), Neni Supriyanti (2009), Sahara (2013) and Swandayani (2012). The result of the $R^{2}$ of the model is 0.890 and adjusted $R^{2}$ is 0.875 . The result of adjusted $R^{2}$ means $87.5 \%$ of dependent variable $(R O A)$ is explained by the combination of variation of independent variables which are Size, OER, NPM, FDR, and $\mathrm{BI}$ rate. The rest of $12.5 \%$ is affected by other factors outside the research model.

\subsection{Classical Assumption for ROA Determinants}

\section{Normality Test}

Probability value of J-B is 0.104 which mean more than 0.05 , it is indicated that the data has a normal distribution, see table 6. Based on Santosa and Ashari (2005), normality test is a test to know whether the data distribution is normal or not.

\section{Autocorrelation Test}

Since the D-W value of data analyzed is 1.702 , which mean is between -2 and 2 , the data has no autocorrelation problem. Based on Singgih Santoso (2009), the result of 
D-W value lower than -2 means that there is a positive autocorrelation problem and higher than 2 indicates negative autocorrelation problem $(-2 \leq D W<2)$. See table 5 .

\section{Multicollinearity Test}

Hence, the value of all the independent variables are below than 0.7 the result shown that there is no multicollinearity problem in this regression model, see table 7 . This research was used the significant level sig $=5 \%$ and the multicollinearity problem will be accrued when the value is more than 0.7 According to Moore, Notz \& Flinger, 2013.

\section{Heteroscedasticity Test}

Based on the result from the white test model it shown the Obs ${ }^{*} \mathrm{R}$-squared is 28.673 with the probability value is 0.094 and it is more than 0.05 . Therefore, this regression model is free from heteroscedasticity problem, see table 8 . This test was determined whether the variance from the residual of the observation variable is similar or not in the regression model.

\subsection{Technical Efficiency Result}

Based on Data Envelopment Analysis, Islamic commercial banks are classify to be technical efficiency is the efficiency score is equal to one. The research discusses the comparative efficiency score of every banks sample for every quarter and also technical efficiency of the specific banks sample. The result shows that BNIS has better technical efficiency compared to another banks sample. The average technical efficiency of BNIS is 0.961 or $96.1 \%$. It means BNIS still used averagely $96.1 \%$ of inputs to produce its maximum outputs. It is indicated that BNIS still cannot maintain its technical efficiency to be optimum. Projection result from MaxDea software especially from the inputs side need concern to be improve such as total funds and fix assets, moreover BNIS should concern regarding reduce the employees expense. According to Rahmawati (2015) cutting employees expense and allocate it to another activity regarding to gain more feedback or profit to the bank. All the inputs side for BNIS are really need to pay attention, whereas all factors are not good. Moreover, for the total mean of Islamic commercial banks period 2012Q1 - 2016Q2 is 0.919 or $91.9 \%$ means that the averagely value for all of the bank are inefficient because below than 1 or $100 \%$.

\subsection{Simple Regression Model Result}

This research use simple regression to find out the relationship between technical efficiency and ROA by adopted Common Effect Method. The results are presented in table 5 . 


\section{Table 5: Simple Regression Result of Technical Efficiency and ROA Relationships}

\begin{tabular}{|c|c|c|c|c|}
\hline $\begin{array}{l}\text { Dependent Variable: } \\
\text { Method: Panel Least } \\
\text { Date: } 12 / 14 / 16 \text { Time } \\
\text { Sample: } 172 \\
\text { Periods included: } 4 \\
\text { Cross-sections inclu } \\
\text { Total panel (balanced } \\
\text { White cross-section }\end{array}$ & $\begin{array}{l}18 \\
\text { servations: } 7 \\
\text { dard errors \& }\end{array}$ & $\begin{array}{l}2 \\
\text { covariance (d }\end{array}$ & corrected) & \\
\hline Variable & Coefficient & Std. Error & t-Statistic & Prob. \\
\hline $\begin{array}{c}\text { ROA } \\
\text { C }\end{array}$ & $\begin{array}{l}0.000161 \\
0.918390\end{array}$ & $\begin{array}{l}0.036915 \\
0.052386\end{array}$ & $\begin{array}{l}0.004349 \\
17.53112\end{array}$ & $\begin{array}{l}0.9965 \\
0.0000\end{array}$ \\
\hline \multicolumn{5}{|c|}{ Effects Specification } \\
\hline \multicolumn{5}{|c|}{ Cross-section fixed (dummy variables) } \\
\hline $\begin{array}{l}\text { R-squared } \\
\text { Adjusted R-squared } \\
\text { S.E. of regression } \\
\text { Sum squared resid } \\
\text { Log likelihood } \\
\text { F-statistic } \\
\text { Prob(F-statistic) }\end{array}$ & $\begin{array}{r}0.250852 \\
-0.003575 \\
0.107275 \\
0.609923 \\
69.59561 \\
0.985948 \\
0.489088\end{array}$ & $\begin{array}{l}\text { Mean depen } \\
\text { S.D. depend } \\
\text { Akaike info } \\
\text { Schwarz crite } \\
\text { Hannan-Qui } \\
\text { Durbin-Wats }\end{array}$ & $\begin{array}{l}\text { nt var } \\
\text { t var } \\
\text { rion } \\
\text { on } \\
\text { criter. } \\
\text { stat }\end{array}$ & $\begin{array}{r}0.918558 \\
0.107084 \\
-1.405434 \\
-0.804647 \\
-1.166259 \\
2.614308\end{array}$ \\
\hline
\end{tabular}

Source: Adjusted by Author, processing result on secondary data (Eviews version 8)

Based on Andries (2013) the result shows that there is no direct relationships between technical efficiency and ROA. According to Fathony (2015) found that there is no relationships between technical efficiency and ROA. The positive value of profitability does not mean always support that the value of bank efficiency is better or even bad and vice versa. Other research by Wahab (2015) agree this result that ROA positive and insignificant to TE. This research result is similar with the previous research that the value between technical efficiency and ROA is has a positive and not significant. The classical assumption of relationships between technical efficiency and ROA is cannot fulfilled.

\section{Conclusions}

The ROA Ratio of Islamic Commercial Banks in Indonesia period of 2012Q1-2016Q2 is variation range from $-0.040 \%$ until $2.560 \%$. The Size, OER, NPM, FDR, and BI Rate partially and simultaneously effect on ROA of Islamic commercial banks. The Size, NPM, and FDR have positive significant effect on ROA. Meanwhile, OER and BI Rate have negative significant effect on ROA. Hence, Size, OER, NPM, FDR, and BI Rate have simultaneously effect on ROA. The technical efficiency of Islamic commercial banks period 2012Q1-2016Q2 is averagely to $91.9 \%$. It indicates that Islamic commercial banks are inefficient regarding managing the technical and averagely used $91.9 \%$ of inputs to achieve the maximum outputs. However, in several banks in several periods, the Islamic commercial banks achieve fully efficient level. The result shows that BNIS is the most technical efficiency compared to other Islamic commercial banks in this research which the average value is $96.1 \%$. The relationship between technical efficiency and return on assets (ROA) is not significant. In the other words, the increasing of the profitability does not affect the value of technical efficiency and vice versa. This finding indicates there is no direct relationship between both variables. 
Proceedings of 12th Asia-Pacific Business Research Conference 27 - 28 February, 2017, Concorde Hotel, Kuala Lumpur, Malaysia ISBN: 978-1-925488-29-6

\section{References}

Abduh, Muhammad \& Omar, Mohd Azmi. 2012. Profitability Determinants of Islamic and Conventional Banks in Malaysia: A Panel Regression Approach. Terrengganu International Business and Economics Conference 2012.

Abdul Wahab, Muhamad Nadratuzzaman Hosen \& Syafaat Muhari, 2015. "Komparasi Efisiensi Teknis Bank Umum Konventional (BUK) Dan Bank Umum Syariah (BUS) Di Indonesia Dengan Metode Data Envelopment Analysis (DEA)". Fakultas Syariah dan Hukum UIN Syarif Hidayatullah Jakarta.

Andries, Alin Marius. 2013. "The determinants of bank efficiency and productivity growth in the Central and Eastern European banking system". Faculty of Economics and Bussiness Administration. Alexandru loan Cuza University of lasi

Alothman, M., Bhat, R. and Karim, A.A. (2009) Antioxidant Capacity and Phenolic Content of Selected Tropical Fruits from Malaysia, Extracted with Different Solvents. Food Chemistry, 115, 785-788.

Ameur, I and Mhiri, S. 2013. Explanatory Factors of Bank Performance Evidence from Tunisia, International Journal of Economics, Finance and Management, Vol. 2, No.1.

Amirillah, M.A. 2010. Efisiensi Perbankan Syariah di Indonesia Tahun 2005-2009 (Tesis). Semarang: Universitas Diponegoro.

Ascarya dan Yumanita, Diana. (2005). Bank Syariah: Gambaran Umum, Pusat Pendidikan dan Studi Kebanksentralan (PPSK). Jakarta: Bank Indonesia.

Berger, A.N. \& Humphrey, D.B. (1997). Efficiency of Financial Institutions: International Survey and Directions for Future Research.

Chapra, umer. 2008. "The Global Financial Crisis: Can Islamic Finance Help Minimize the Severity and Frequency of Such a Crisis in the Future?; A Paper prepared for presentation at the Forum on the Global Financial Crisis, Islamic Development Bank.

Charnes A, Cooper W.W, Rhoads E. (1978).Measuring the efficiency of decision making units.

Circular letter of Indonesia central bank to all commercial banks based on syaria principles in Indonesia No. 9/24/DPbs, Jakarta, October 30, 2007.

Dendawijaya, Lukman. 2005. Manajemen Perbankan. Jakarta: Ghalia Indonesia.

Ekonomi Makro Islam. PT. Rajagrafindo Persada. Adiwarman A Karim. 2006.

Fathony, Moch. 2013. "Analisis Efisiensi Perbankan Nasional Berdasarkan Ukuran Bank: Pendekatan Data Envelopment Analysis", Finance and Banking Journal, vol. 15 (1).

Gujarati. 2005. SPSS Versi 16 Mengolah Data Statistik Secara Profesional. Jakarta: Gramedia Pustaka Utama.

Hoque, M. R., \& Rayhan, D. M. (2012). Data Envelopment Analyis of Banking Sector In Bangladesh. Russian Journal of Agricultural and Socio-Economic Sciences, 5 (5), 17-22.

Law of Banking the Republic of Indonesia Number 23 of 2004 Muh. Sabir. M,

Moore, D. S., Notz, W. I, \& Flinger, M. A. (2013). The basic practice of statistics (6th ed.). New York, NY: W. H. Freeman and Company

Muhammad Ali, Abd. Hamid Habbe, Manajemen dan Keuangan, Fakultas Ekonomi dan Bisnis Unhas Makassar Jurnal Analisis, Juni 2012, Vol.1 No.1: 79 - 86. 
Muhamad Abduh, Mohd Azmi Omar (2012) International Journal of Islamic and Middle Eastern Finance and Management Emerald Group Publishing Limited

Nainggolan. Marnov P.P (2009) Analisis Pengaruh LDR. NIM dan BOPO Terhadap ROA Bank Umum Indonesia. Skripsi. USU Repository.

Neni Supriyanti (2009). Analisis Pengaruh Inflasi Dan Suku Bunga BI Terhadap Kinerja Keungan PT. Bank Mandiri, TBK Berdasarkan Rasio Keuangan. Universitas Gunadarma.

Rahmawati, 2015. Analisis Pengaruh CAR, NPL, LDR, NIM, Dan BOPO Terhadap ROA Dengan GCG Sevagai Variable Kontrol. Universitas Diponegoro.

R. D. Banker, A. Charnes and W. W. Cooper Management Science, 1984, vol. 30, issue 9, pages 1078-1092

R.A. Supriyono (2007). Manajemen Biaya; Suatu Reformasi Pengelolaan Bisnis. Yogyakarta: BPFE Yogyakarta.

Sahara, Ayu Yanita. 2013. Analisis Pengaruh Inflasi, Suku Bunga BI, Dan Produk Domestik Bruto Terhadap Return On Assets (ROA) Bank Syariah Di Indonesia. Universitas Negeri Surabaya : Surabaya.

Santosa, Purbayu Budi, dan Ashari, 2005, Analisis Statistik dengan Microsoft Excel dan SPSS, Penerbit Andi, Yogyakarta.

Sartika, D., 2012. Analisis pengaruh ukuran perusahaan, kecukupan modal, kualitas aktiva produktif dan likuiditas terhadap return on assets (ROA). Makassar: Universitas Hasanuddin.

Sastrosuwito, S. and Y. Suzuki, 2012. The determinants of post-crisis Indonesian banking system profitability. Economic and Finance Review, 1(11): 48-57.

Schwert, G.W., 2010. Descriptive statistics. Available from EViews 7 User's Guide I: http://schwert.ssb.rochester.edu/a425/EV72.pdf [Accessed April 29, 2014].

Seibel. Hans Dieter., (2008). Islamic microfinance in Indonesia: the challenge of institutional diversity, regulation and supervision, research notes and comment. Journal of Social Issues in Southeast Asia, 23 (1), 66-103.

Sekaran, U., \& Bougie, R. (2011). Research methods for business: A skill building approach. UK: Wiley.

Setiawan, C. and M.E. Putri, 2013. Non-performing financing and bank efficiency of islamic banks in Indonesia. Journal of Islamic Finance and Business Research, 2(1): 58-76.

Setiawati, Alifta Kurnia \& Setiawan. 2013. Pemodelan Persentase Penduduk Miskin di Jawa Timur dengan Pendekatan Ekonometrika Panel Spasial, dari http://digilib.its.ac.id/public/lTS-paper- 24626-1308100061-Paper.pdf, downloaded at 21 Mei 2013.

Setyo Budi Nugroho. 2011. Analisis Pengaruh Efisiensi Modal Kerja, Likuiditas dan Solvabilitas terhadap Profitabilitas (Studi Kasus pada PT. Telekomunikasi Indonesia, Tbk.).

Sherman HD and F Gold (1985). "Bank Branch Operating Efficiency." J Banking and Finance 9(2): 297-315.

Short, B.K. (1979) 'The relation between commercial bank profit rates and banking concentration in Canada, Western Europe and Japan', Journal of Banking and Finance, Vol. 3, pp.209-219.

Sianturi, Maria R. R. 2012. Pengaruh CAR, NPL, LDR, NIM, dan BOPO terhadap Profitabilitas Perbankan (Studi Kasus pada Bank Umum yang Listed di Bursa Efek Indonesia Tahun 2007 - 2011). Makassar: Universitas Hasanuddin. 
Singgih Santoso. (2009). Panduan Lengkap Menguasai Statistik Dengan SPSS. Jakarta: PT. Elex media komputindo.

Siraj, K., and Pillai, P. S. 2012. Comparative Study on Performance of Islamic Banks and Conventional Banks in GCC Region. Journal of Applied Finance and Banking, 149.

Smirlock, M. (1985) 'Evidence on the (non) relationship between concentration and profitability in banking', Journal of Money, Credit, and Banking, Vol. 17, pp.6983.

Snedecor GW, Cochran WG, (1980). Statistical methods. 7th edition. The lowa State University Press, Ames, lowa.

Syafri, M. (2012, 9 7-8). Factors Affecting Bank Profitability in Indonesia. The 2012 International Conference on Business and Management, 237.

Swandayani, Desi Marilin \& Kusumaningtias, Rohmawati. 2012. Pengaruh Inflasi, Suku Bunga, Nilai Tukar Valas Dan Jumlah Uang Beredar Terhadap Profitabilitas Pada Perbankan Syariah Di Indonesia Periode 2005-2009. AKRUAL 3 (2) (2012) : 147-166 e-ISSN : 2502-6380. Universitas Negeri Surabaya : Surabaya.

Torres-Reyna, O. (2007). Panel Data Analysis Fixed and Random Effects using Stata. Werdaningtyas, Hesti, 2002, "Faktor yang Mempengaruhi Profitabilitas Bank Take Over Pramerger di Indonesia", Jurnal Manajemen Indonesia, Vol.1, No.2, pp.24-39.

Weston, J.F. and Copeland, T.E. (1998) Managerial Finance. CBS College Publishing, New York, 243-255.

Widarjono, Agus (2007). Ekonometrika: Teori dan Aplikasi Untuk Ekonomi dan Bisnis, edisi kedua. Yogyakarta: Ekonisia FE Universitas Islam Indonesia.

Zhu, J., 2009. Quantitative models for performance evaluation and benchmarking data envelopment analysis with spreadsheets. USA: Springer. 
Proceedings of 12th Asia-Pacific Business Research Conference 27 - 28 February, 2017, Concorde Hotel, Kuala Lumpur, Malaysia ISBN: 978-1-925488-29-6 